\title{
PARA A BOA ADMINISTRAÇÃO DA JUSTIÇA: a inserção dos Juizes de Fora e a promoção de mudanças no judiciário da Colônia no final do século XVII
}

\author{
Marcelo Lunardi Carmo*
}

\begin{abstract}
RESUMO: A historiografia que trata sobre a inserção dos juízes de fora, credita a criação desses cargos a uma tentativa da coroa de aumentar seu controle sobre as câmaras de importantes cidades. No presente artigo pretendemos demonstrar que as motivações das autoridades régias ultrapassavam a esfera econômica. A aplicação da justiça na colônia estava numa situação muito precária, e era necessário intervir para alterar esse contexto. Além da nomeação dos juízes de fora, outras medidas foram empreendidas no período visando uma boa administração da justiça na colônia.

PALAVRAS-CHAVE: Brasil colônia; Justiça; Juiz de fora; Século XVII.
\end{abstract}

\section{For the proper administration of justice: the insertion of juízes de fora and the promotion of changes in the colony's judiciary in the late seventeenth century.}

ABSTRACT: Historiography dealing with the insertion of juízes de fora credits the creation of these offices to an attempt by the crown to increase its control over the chambers of important cities. In this article, our aim is to show that the motivations of the royal authorities went beyond the economic sphere. The application of justice in the colony was in a very precarious situation, and it was necessary to intervene to change this context. In addition to the appointment of the juízes de fora, other measures were designed to evaluate the proper administration of justice in the colony.

KEYWORDS: Brazil colony; Justice; Juiz de fora; 17th century.

\section{Para la buena administración de la justicia: la inserción de los juízes de fora y la promoción de cambios en el poder judicial de la colonia a finales del siglo XVII.}

RESUMEN: La historiografía que trata sobre la inserción de los juízes de fora, acredita la creación de esos cargos a un intento de la corona de aumentar su control sobre las cámaras de importantes ciudades. En el presente artículo pretendemos demostrar que las motivaciones de las autoridades regias superaban la esfera económica. La aplicación de la justicia en la colonia estaba en una situación muy precaria, y era necesario intervenir para cambiar ese contexto.

Además del nombramiento de los juízes de fora, otras medidas fueron emprendidas en el período para una buena administración de la justicia en la colonia.

PALABRAS CLAVE: Brasil colonia; Justicia; Juiz de fora; Siglo XVII.

\footnotetext{
* Mestre em História Econômica pelo Programa de Pós-graduação da Faculdade de Filosofia, Letras e Ciências Humanas da Universidade de São Paulo. Atualmente é técnico para assuntos administrativos da Universidade de São Paulo. Contato: Universidade de São Paulo (USP), Cidade Universitária, CEP: 05508-900, São Paulo - SP, Brasil. E-mail: marcelolcarmo@usp.br. ORCID: http://orcid.org/0000-0002-4347-1705.
} 
Uma das principais atribuições dos monarcas no âmbito do Antigo Regime era prover a justiça a seus vassalos ${ }^{1}$. Um trecho do regimento dado por D. Pedro ao governador geral do Brasil, Roque da Costa Barreto, em 1677, deixa bem claro a importância da administração da justiça: “[...] a Justiça é de tão grande e particular obrigação minha, e tão necessária para a conservação e acrescentamento dos Estados, que tudo o que na administração dela encarregar será muito menos do que desejo",2.

Apesar de ser uma importante atribuição régia, nas últimas décadas do século XVII essa prerrogativa não vinha sendo bem exercida no Brasil. O número de oficiais régios não era suficiente para garantir um bom governo da justiça e a colonização de terras cada vez mais distantes dos grandes centros urbanos dificultava ainda mais a aplicação das leis, dado a distância e péssima qualidade dos caminhos.

Em 1681, o então príncipe regente, D. Pedro ${ }^{3}$ solicitou informações sobre o estado em que se encontrava a justiça no Brasil e as dificuldades enfrentadas pelos magistrados para aplica-la, pediu ainda sugestões de como solucionar os problemas ${ }^{4}$. Os questionamentos foram encaminhados a dois indivíduos, Sebastião Cardoso de Sampaio e Cristóvão de Burgos, que haviam feito boa parte de suas carreiras na judicatura no ultramar, tendo servido, dentre outros cargos, na Relação da Bahia ${ }^{5}$, e conheciam bem os problemas enfrentados pelos ministros na aplicação das leis no Brasil. Seus pareceres foram a base para uma significativa mudança na estrutura do judiciário da colônia no final do século XVII.

Dentre as mudanças sugeridas pelos dois magistrados consta a inserção dos juízes de fora na estrutura judiciária da colônia. A trajetória de criação desse cargo, como pretendemos desvelar nesse artigo, vai de encontro a tese defendia por Stuart Schwartz, na clássica obra "Burocracia e Sociedade no Brasil Colonial", segundo o autor o oficio teria sido criado após sucessivas solicitações do governador geral D. João de Lencastre.

Em agosto de 1677, os desembargadores da Relação haviam alertado as autoridades do Reino para a necessidade de um juiz de fora presidir a câmara de Salvador. Segundo relatavam os ministros do tribunal, a presença de um juiz letrado tornaria mais eficaz a administração da justiça e evitaria os descaminhos das rendas da câmara. Além disso, acabaria com as parcialidades com que habitualmente os juízes ordinários julgavam as causas. Com a criação do novo oficio a coroa teria “ [...] um ministro seu na Câmara de uma cidade tão principal como a da Bahia para com mais suavidade poder obrar nela o que conviesse a seu serviço" 
Citando essa carta dos desembargadores Schwartz (1979) afirma que: “[...] a Coroa não agiu imediatamente baseada nesta recomendação, mas em 1696, [...], essa medida foi instituída em virtude da insistência de Dom João de Lencastre, o ativo e imaginoso governador-geral do Brasil" 7 .

A tese de Schwartz (1979) está presente em boa parte da historiografia que trata sobre a justiça no Brasil colonial, desde os trabalhos clássicos, até os mais recentes. Salgado (1985) afirma, após citar Schwartz, que “ [...] foi para atender a essas reivindicações que no final do

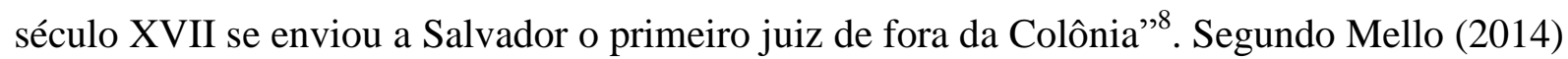
“ [...] para os desembargadores era fundamental a presença de mais um ministro régio na câmara da cidade. A ideia era implantar um magistrado de forma mais efetiva na câmara e melhorar a administração da justiça. O pedido dos magistrados só foi atendido anos depois, devido a insistência do governador-geral [...]"9.

Como pretendemos demonstrar não apenas o ofício de juiz de fora, mas outras importantes alterações na estrutura do judiciário da colônia, foram implementadas após serem analisados, e debatidos, no Conselho Ultramarino os pareceres de Sebastião Cardoso e Cristóvão de Burgos; documentos que foram elaborados a pedido da coroa, deixando assim transparecer uma evidente intencionalidade das ações régias que também teve, como não poderia deixar de ser, fortes motivações econômicas ${ }^{10}$. Na segunda metade do século XVII o Brasil passou a ser o centro das atenções régias, “[...] num primeiro momento pelo seu elevado potencial agrícola, e depois, graças à descoberta de metais preciosos, o território conhecerá uma presença mais pesada do aparelho de administração régia"11. Contudo não podemos creditar as mudanças promovidas no judiciário, nos últimos anos do século XVII, apenas a motivações econômicas. As ações também não podem ser justificadas apenas pelo intento régio de aperfeiçoar seus mecanismos de controle sobre a colônia. Pretendia-se conceder aos súditos, na medida do possível, uma justiça de melhor qualidade do que aquela a que tinham acesso no Brasil, que, a darmos crédito aos relatos feitos pelos dois magistrados, encontrava-se em situação calamitosa, como veremos.

\section{O parecer de Sebastião Cardoso de Sampaio}

Em janeiro de 1681, atendendo à solicitação de D. Pedro, Sebastião Cardoso apresentou um parecer sobre o estado em que se encontravam a justiça e fazenda do Brasil. No documento, constituído de 13 tópicos ${ }^{12}$, apresenta aquilo que pela sua experiência seriam os maiores problemas enfrentados para o bom governo dessas atividades e sugere soluções. 
Cardoso era formado em cânones pela Universidade de Coimbra. Em 1660, foi eleito ouvidor-geral da capitania do Rio de Janeiro. Sendo designado em 1669 como desembargador sindicante de Angola, retornou ao Brasil e em 1675 assumiu o cargo de chanceler da Relação da Bahia. Os serviços prestados no ultramar garantiram lhe uma promoção a um posto no Reino, sendo eleito para o Conselho Ultramarino em julho de 1685. Segundo Mello (2009) Sampaio “[...] gozava de considerável prestígio na Corte e, como conselheiro do Rei, participava em várias juntas informais, sendo o seu conselho solicitado mesmo em matérias que extrapolassem suas atribuições funcionais". Ainda no Reino, assumiria o posto de chanceler da Relação do Porto, em 1688, chegando a governador do mesmo tribunal em 1691. O ápice de sua carreira foi sua nomeação para o Desembargo do Paço em $1695^{13}$.

Logo no início do manuscrito, Cardoso aponta como principal obstáculo à correta aplicação da justiça o crescimento das povoações, que vinham sendo erigidas cada vez mais distantes das grandes cidades. Segundo ele “ [...] o estado do Brasil se acha hoje tão aumentado, que a cidade da Bahia passa de três mil vizinhos e no Recôncavo e sertão com inumerável gente e a esse respeito no seu tanto as mais capitanias, estendendo-se tanto as povoações que os moradores que estão no interior do sertão ficam a mais de cem léguas apartados de cada uma das capitanias", esse problema era vivenciado principalmente na Bahia. Por não existirem ministros da justiça nas povoações do interior e pela impossibilidade desses darem expediente nelas constantemente, os moradores do sertão eram prejudicados: “[...] ou perdem as suas dívidas por dificuldade de as pedirem por justiça ou as cobram com violência”. Mesmos em localidades que contavam com juízes ordinários ${ }^{14}$, a situação não era melhor, pois esses fundavam suas decisões no poder das elites locais. A impunidade de que gozavam os infratores nas localidades mais afastadas representava também um problema, já que "[...] os delinquentes depois de cometerem seus insultos ficam no lugar do delito escandalizando a alguns e persuadindo aos demais com o mal exemplo, sem chegarem nem ainda a terem o susto de homiziados, acuando no seguro de que não há justiça que os castigue" ${ }^{\prime 15}$

Para resolver esse problema Cardoso sugere a criação de conselhos, nas localidades mais distantes dos grandes centros. A solução seria dividir “[...] tudo o que está povoado naquele Recôncavo e sertão e no mais das outras capitanias, em conselhos na forma que está dividido este Reino, mandando criar neles juízes ordinários e oficiais da Câmara para acudirem ao governo dos povos e administração da justiça". Contudo, antes da criação dos novos conselhos municipais, seria necessário promulgar um regimento para os oficiais da 
justiça pois, muitas normas dadas pelas Ordenações Filipinas não se podiam aplicar ao Brasil dado a "[...] largueza dos moradores e carestia das terras". Muitos juízes e magistrados se aproveitavam dessa situação e cobravam valores muito elevados pelos seus serviços, o que gerava constantes queixas ${ }^{16}$.

Reclamações também surgiam da aplicação da prerrogativa que tinham o chanceler da Relação e o governador-geral de perdoar delitos e comutar as penas de degredo em outras mais leves. Segundo Sebastião Cardoso, essas autoridades vinham concedendo o apanágio indiscriminadamente o que gerava "[...] grande escândalo e prejuízo da justiça" ${ }^{17}$ pois, até os crimes mais graves acabavam perdoados. O envio anual da relação dos perdões concedidos e degredos comutados para a apreciação das autoridades do Reino era apontado como a solução mais viável.

No sexto tópico do parecer Cardoso relata mais uma dificuldade que os oficiais de justiça enfrentavam para aplicar a lei no sertão. Os problemas decorriam não apenas das grandes distâncias entre as povoações, mas principalmente, porque as terras pertenciam a um pequeno grupo de indivíduos, que por diversas vezes impediam a ação das autoridades régias. Segundo o magistrado esse problema tinha tido início com a doação de sesmarias no sertão.

Enquanto no Recôncavo "[...] se repartiram com igualdade as sesmarias de terras que então se deram", deixando os moradores com "[...] a terra que precisamente lhe é necessária para a lavoura que faz e sua fábrica", a concessão de sesmarias no sertão não seguiu esses critérios. No Recôncavo as sesmarias doadas “[...] foram somente de duas, e três e quatro mil braças e a maior não passou de quatro léguas”, já no sertão as terras não foram limitadas por “ [...] braças, ou léguas como as primeiras, mas por confrontações e termos distantíssimos, de serras e rios, por exemplo como desde o Minho até o Douro ou deste até o Tejo ou Guadiana”. Com isso, alguns moradores passaram a ser donos de grandes extensões de terra, alguns com sesmarias de 80 ou 100 léguas, e a maioria dessas permaneciam improdutivas ${ }^{18}$.

Para melhorar a justiça no Brasil seria imprescindível que essas terras fossem redistribuídas, o que, segundo Cardoso, poderia ser feito através de ordem régia, já que a concessão de áreas tão extensas a poucos indivíduos era um ato passível de anulação. Isso porque muitos dos beneficiários das grandes sesmarias do sertão baiano eram donos de terras também em outras capitanias, informação que certamente tinham omitido no momento da solicitação da mercê. Mesmo a alegação constantemente usada pelos grandes sesmeiros, de que suas possessões se encontravam sem lavouras para serem utilizadas como pasto para o 
gado, era refutada pelo autor do parecer, já que existiam ordens régias que determinavam que os pastos deveriam ser comuns e não particulares. Ademais não seria licito ao rei:

\begin{abstract}
querer nem permitir que quase todas as terras desta ou outra qualquer capitania se juntem na pose de dez ou doze homens somente, para assim se reduzir e cortar ao arbítrio e dependência de tão poucas pessoas a povoação e cultura do sertão deste estado, ficando desta sorte todos os outros vassalos que o quiserem penetrar para nele fazer assistência e exercer a lavoura, pensionários e quase súditos aqueles poucos que sem vantagem de outro merecimento mais que o da antecipação do petitório se fizeram senhores de tantas terras as quais de presente tem na maior parte vagas, sem ocupação nem cultura, podendo elas ser mais miudamente repartidas por outros que logo ocupem e cultivem suas sesmarias moderadas, e delas colham frutos não só em utilidade sua mais também dos direitos de Vossa Alteza ${ }^{19}$.
\end{abstract}

A solução desse problema iniciar-se-ia pelo recolhimento de todas as cartas de doação de sesmarias de mais de quatro léguas, após uma análise criteriosa da forma de utilização da terra e do cabedal do beneficiário, a posse poderia ou não ser confirmada. Nesse momento, deveriam ser respeitados aqueles que tiveram trabalho e dispêndio "[...] na abertura dos caminhos, na oposição feita ao gentio bravo, na danosa resistência a suas incursões e hostilidades e finalmente na boa diligência que hão feito em reduzir e pacificar o mesmo gentio". Aqueles que houvessem procedido bem fariam jus a continuar com suas terras mas, “[...] com condição que cada cinquenta ou sessenta anos serão obrigados por si ou por seus vindouros a confirmar de novo suas sesmarias, com prova de como as ocupam e cultivam com diligência" 20 .

O recolhimento das cartas de sesmarias e a redistribuição das terras do sertão era uma solicitação antiga de Sebastião Cardoso. Em 1675 o magistrado, a pedido da coroa, realizou uma devassa nos registros de doações de sesmarias, deparando-se com muitos abusos que tinham sido cometidos. No relatório da devassa, remetido ao Conselho Ultramarino, Cardoso apresenta um documento intitulado "Memoria das pessoas que possuem grandes sesmarias nas capitanias do Brasil, conforme as suas declarações e informações que tomou". Nesse manuscrito, datado de 26 de julho de 1675, Sebastião Cardoso elenca as pessoas que se declararam grandes sesmeiros. Dentre eles, encontramos a figura de João Peixoto Viegas que “[...] declarou possuir trinta léguas de terra que houve por compra e possui uma sesmaria que lhe concedeu desde Jacuípe até Peruaçu. Não se pode averiguar ao certo as léguas que são, mas se avaliam em mais de cento e vinte léguas". Apesar da grande extensão das terras de Viegas, Cardoso alega que ele tinha feito muitos gastos para abrir caminhos e domesticar o gentio, e isso deveria ser considerado no momento de uma nova divisão de terras. Além de Viegas são citados no documento, como grandes sesmeiros do sertão baiano: Gaspar Roiz 
Adorno, sargento-mor Pedro Borges Pacheco, capitão Sebastião Barbosa de Almeida, Agostinho Pereira Vaselar, capitão Francisco Barbosa Leal, coronel Francisco Gil de Araújo, sargento-mor Lourenço de Brito de Figueiredo, capitão Garcia de Ávila, Dona Lourenço Doria e seu filho Bernardo de Afonseca, mestre de campo Pedro Gomes, mestre de campo Antônio Guedes de Brito e um capitão de sobrenome Almeida cujo prenome encontra-se ilegível no documento ${ }^{21}$.

Os relatórios sobre a devassa das sesmarias foram vistos no Conselho Ultramarino em julho de 1676. O procurador da fazenda concordou com o recolhimento das cartas de sesmarias, proposto por Sebastião Cardoso, e com a nova divisão das terras do sertão baiano. Sugeriu o procurador que a repartição ficasse a cargo de Cardoso e do governador geral, esses teriam autonomia para realizarem a nova divisão "[...] como mais acharem convém a conservação e aumento daquele Estado, conveniência dos vassalos e serviço de Vossa Alteza”. Já os demais membros do Conselho não concordaram com o parecer do procurador. Alegavam que apesar de Cardoso ter obrado bem na tarefa, “[...] era certo que se se houvesse de executar o que se mandava de novo, haveria mister muitos anos"22. Com isso, a ideia de uma nova divisão das terras da capitania da Bahia foi arquivada, contudo o magistrado retomaria a questão em 1681, no seu parecer sobre a situação da justiça no Brasil, por considerar que o problema era grave e deveria ser remediado pela coroa.

Concluindo seu parecer Cardoso aponta ainda, que o fato das câmaras administrarem o recolhimento de impostos e contribuições gerava muitos transtornos aos residentes, tanto da Bahia como de outras capitanias. Isso ocorria, pois, os oficiais decidiam sobre as cobranças diminuindo ou aumento as imposições sobre "[...] cada um dos moradores segundo seus ódios ou afeições". Em alguns casos chegaram a conceder isenções de impostos a si mesmos, durante o período que estavam a serviço da câmara. Para sanar esse problema, deveria ser criada uma junta, formada por pessoas nobres e plebeias. Esses indivíduos seriam responsáveis pela administração da arrecadação de tributos e contribuições, sendo essa prerrogativa retirada das câmaras.

\section{O parecer de Cristóvão de Burgos}

Em agosto de 1681 Cristóvão de Burgos encaminhou seu parecer sobre a situação da justiça no Brasil.

Cristóvão nascera na Bahia. Filho de pai letrado, cursou direito civil em Coimbra e em 1644 ingressou no serviço régio. Inicialmente ocupou o cargo de juiz de fora da cidade de 
Ponta Delgada, na Ilha de São Miguel no Arquipélago dos Açores, onde exerceu também o cargo de superintendente da moeda, tendo sido ainda corregedor da ilha de Santa Maria. Foi eleito posteriormente para ocupar o posto de desembargador dos agravos da Relação da Bahia em 1653, assumindo o cargo em 22 de janeiro de 1654, esteve a serviço do tribunal por 26 anos. Além do cargo para o qual foi incialmente provido, assumiu a função de ouvidor-geral do crime, posteriormente chegando a chanceler - máximo nível hierárquico da instituição -, passando assim a presidir a Relação. O reconhecimento de seus serviços no ultramar o levou a assumir um posto na Casa de Suplicação, tribunal superior do Reino. Casou-se em novembro de 1651 com Helena da Silva Pimentel, filha de Bernardo Pimentel de Almeida parente do governador do Brasil, Luís de Brito de Almeida ${ }^{23}$.

O parecer de Burgos, bastante extenso e detalhado, divide-se em três partes, inicia com a apresentação dos problemas enfrentados pelos ministros letrados na aplicação da justiça. Discorre sobre a situação da Fazenda Real, concluindo com as indicações dos remédios a serem aplicados.

O primeiro problema descrito por Cristóvão foi a falta de oficiais régios para atender as novas povoações, que vinham sendo construídas cada vez mais distantes de Salvador:

\begin{abstract}
Antigamente e isso a 60 anos bastava ter na Bahia um ouvidor porque a gente era menos e quando sucedia uma morte na cidade ou em seu termo era de 10 em 10 anos. Mas hoje que tem crescido a gente e os povos e isso de tal forma que a freguesia de São Tiago que está distante da cidade oito ou dez léguas por mar e mais de doze por terra (essa trago como exemplo) a muitos anos se dividiu em três paroquias por ser muita gente como agora, e aos poucos se tem dividido muitas outras e só no lugar da Cachoeira e seu distrito que é um dos que se dividiram da freguesia de São Tiago me afirmaram haver 600 homens de armas e estão sucedendo duplicadas mortes cada dia só no Recôncavo. Não pode um ouvidor e dois juízes ordinários que não fazem nada e não sabem o que hão de fazer, acudir a Cidade, acudir a todos os delitos e lugares, porque são muitas e muito distantes por mar seis, oito, dez, quinze e vinte léguas da dita cidade. Mal poderão os ministros que dela se afastem tão longe sendo tão pouco a fazer em todas as partes sua obrigação. E por esta causa sucede que não acodem logo que acontece os delitos como era bem, e ainda onde podem chegar se dilatam as diligencias e onde não podem chegar ficam por fazer e não pode haver maior desordem e embaraço que a haver de se administrar a justiça como lhe é bem ${ }^{24}$.
\end{abstract}

A falta de ministros, que pudessem aplicar penas, cultivava nos criminosos a sensação de impunidade e esses frequentemente voltavam a delinquir. Problema ainda mais grave enfrentavam as povoações que se encontravam mais distantes de Salvador, "[...] porem entrando para o interior do sertão que está muito povoado em mais de 150 léguas, estão há muitos anos os homens matando-se uns aos outros por pouco mais que nada, averiguando as suas dúvidas e diferenças a espingarda sem haver lá quem acuda"25. 
No parecer são elencados vários crimes que não vinham sendo investigados da maneira necessária. Entre eles estavam “[...] os furtos dos gados e outros que fazem os ladrões formigueiros são com excesso de que também se não pode devassar nem nas correições conhecer sem especial provisão". Contudo, os casos de assassinatos são apresentados pelo desembargador como os mais graves, e que vinham se multiplicando com maior velocidade devido a impunidade: “[...] e só na vila do Penedo e seus arredores no rio de São Francisco do princípio do ano de 1679 até a Pascoa se mataram 7 pessoas a espingarda, poucos são os que se prendem e menos os que chegam a julgamento" 26 .

Não faltavam apenas os ministros necessários para a aplicação das leis, toda a estrutura judiciaria na colônia era deficitária. Como exemplo é citado o caso de Salvador, onde havia apenas 4 tabeliães do judicial, que além de tratar dos registros cartorários serviam junto ao ouvidor geral como escrivães. Isso ocorria pois havia apenas um escrivão designado para auxiliar o ouvidor. O juiz dos órfãos também tinha apenas um escrivão e havia somente 2 inquiridores na capitania. Esse era um número de oficiais insuficiente para atender a todas as demandas, segundo Cristóvão:

\begin{abstract}
Naquele Estado não se pode nunca nem ainda hoje administrar a justiça com a prontidão e inteireza que convém principalmente contra os poderosos. Certas vezes porque os Ministros da justiça andam oprimidos e desfavorecidos dos mesmos que lhes deviam dar a mão e ajudar a faze-la, porque esses os encontram e desviam, e as sentenças se não executam porque tudo se perdoa sem diferença de casos. Outras porque faltam os ministros e oficiais que são necessários para se prover e acudir todas as partes, porque a largueza da terra, as infinitas matas e rios e os longes dificultam mais e impossibilitam o poder se compreender tudo com os poucos ministros e oficiais que estão $l^{27}$.
\end{abstract}

Além da falta de ministros e oficiais, a facilidade com que os poderosos se livravam de acusações era um problema para a aplicação da justiça no Brasil. A concessão de perdões por parte do chanceler da Relação era feita com muita largueza para esses indivíduos, assim “[...] nascia menos temor da justiça e facilitava aos maus a confiança para delinquirem" ${ }^{, 28}$.

Cristóvão de Burgos apresenta ainda mais um problema: a insubordinação dos ouvidores das capitanias às ordens da Relação. Os ouvidores do Rio de Janeiro e Pernambuco não se submetiam a autoridade dos ministros do tribunal, julgavam causas que estavam fora de suas alçadas e não reconheciam as apelações que as partes faziam a Relação.

Para resolver os problemas apontados Burgos faz as seguintes sugestões:

1) que "[...] se devem repartir os lugares do termo e capitania da Bahia em mais jurisdições, ordenando-se vilas e conselhos onde não houver povoação junta”. Nas partes onde houvessem 
poucos moradores, e não fosse possível fazer eleição anual de vereadores e juízes, deveria ao menos se eleger um juiz que tivesse jurisdição sobre o crime;

2) a 40 léguas do distrito dos Campos da Cachoeira, deveria se colocar termo na capitania da Bahia e criar uma nova comarca, no sertão onde "[...] ficam as terras e currais de Sapucurumirim, Massacara, Ribeiras do Rio de São Francisco até a Jacobina e além para adiante que são mais de 100 léguas todas bem povoadas de currais e gente";

3) divididas as jurisdições, deveriam ser criados dois novos ouvidores. Um para a cidade de Salvador, o qual seria responsável pela "[...] petição de todos os agravos crimes que as partes tirarem diante os juízes". Outro para a nova comarca que seria criada no sertão da Bahia "[...] com a mesma jurisdição e poder que o ouvidor da capitania da Bahia";

4) criação do cargo de juiz de fora, um segundo escrivão dos órfãos e um inquiridor para a Bahia;

5) indicação de ouvidores letrados para as capitanias de Sergipe del Rei e Paraíba;

6) aumento da jurisdição do ouvidor de Pernambuco, tornando-o ouvidor geral "[...] das demais capitanias que lhe ficam para o norte a saber: Itamaracá, Paraíba e Rio Grande";

7) criação do cargo de juiz de fora na cidade de Olinda;

8) promulgação de um novo regimento para o ouvidor do Rio de Janeiro, especificando sua jurisdição e os casos que deveriam ser remetidos para análise da Relação;

9) criação do cargo de juiz de fora na cidade de São Sebastião do Rio de Janeiro;

$\mathrm{Na}$ visão do magistrado, com essas ações, a Coroa conseguiria garantir uma aplicação muito mais eficiente da justiça no Brasil. Burgos advoga que era imperativo aumentar o número de oficiais letrados pois "[...] quanto mais longe da presença de Vossa Alteza tanto mais se necessita de bons ministros e letrados",29.

\section{O debate sobre a implantação das mudanças propostas nos pareceres}

Os pareces confeccionados no ano de 1681 foram analisados pelo Conselho Ultramarino apenas 14 anos depois, em 1695. Durante nossa pesquisa não pudemos determinar o motivo de tamanha dilação na análise das mudanças propostas, dado que os pareceres foram escritos por solicitação da coroa. Uma hipótese que levantamos é que como a questão era complexa, foi necessário mais tempo para que os debates sobre a matéria atingissem um consenso. Ademais sempre que as autoridades régias solicitavam informações sobre o caso, essas levavam algum tempo para aportar em Lisboa. 
Em parecer de agosto de 1695 o Conselho foi favorável à criação de novos cargos no judiciário do Brasil. Contudo, pedia que novas informações fossem tomadas com o exgovernador geral, que naquele momento ocupava o cargo de almotacé-mor da corte, António Luís da Câmara Coutinho, sobre a real necessidade desses novos oficiais ${ }^{30}$.

Câmara Coutinho, respondendo em outubro de 1695, defende que os pareceres de Cristóvão de Burgos e Sebastião Cardoso de Sampaio, apontavam boas soluções para os problemas da administração da justiça. Contudo, “[...] como fizeram esses pareceres a 13 anos tem se emendado muitos erros que naquele tempo se cometiam". Segundo o almotacé-mor, uma ordem régia de 1694 já mandava os governadores das capitanias do Brasil juntar os moradores do sertão em conselhos, como sugerido nos pareceres. Porém, isso não era uma tarefa fácil, pois os moradores não deixavam suas terras: “[...] eles não andam, estão em as suas rocinhas de que vivem e é impossível os tirar delas porque não tem em outra parte que comer e não são tantos que façam povoações e ajuntando-se ficam muito longe de suas fazendas para as poderem cultivar". Para Coutinho os governadores, bem como os ministros de justiça, deveriam continuar com essa incumbência, devendo obrar nela com todo o zelo ${ }^{31}$.

Defende o ex-governador que deveriam ser criados dois novos cargos de ouvidor: um na Bahia e outro em Sergipe. Os titulares dessas novas jurisdições deveriam servir também como provedores dos defuntos e ausentes, evitando assim os descaminhos dos recursos administrados pelo titular desse cargo. Para a perfeita aplicação da justiça em Sergipe, seria necessário além do ouvidor que fosse designada uma tropa, para garantir que as sentenças seriam cumpridas. Câmara se mostra favorável a criação do posto de juiz de fora na Bahia, em Pernambuco e no Rio de Janeiro, devendo o titular desse cargo em Salvador acumular a função de juiz dos órfãos. Contudo se mostra indeciso no que tange a criação de novo ofício de escrivão dos órfãos na Bahia, dado que as rendas oriundas das responsabilidades inerentes a esse cargo eram poucas, a criação de um novo posto ocasionaria significativa diminuição de rendimentos. A questão das sesmarias tinha que ser tratada dentro dos limites legais "[...] que se em tanto tempo senão cultivarem fiquem devolutas para Vossa Majestade ou ao seu governador as poderem dar a quem as aproveite e cultive no tempo da mesma lei”. Já o problema dos descaminhos dos recursos administrados pelas câmaras seria resolvido com a designação de juízes de fora, responsáveis pela presidência dessas instituições, e com a auditoria anual das contas, feita pelo chanceler da Relação ${ }^{32}$.

Em novembro de 1695, o Conselho Ultramarino expediu a derradeira consulta que antecedeu a reestruturação do judiciário do Brasil. Pareceu aos conselheiros que aos 
governadores das capitanias deveria ser ordenado que procurassem “[...] ao menos em algumas partes reduzirem-se a povoações os moradores que se acharem espalhados naqueles sertões, quando se não posa conseguir em todo". Concordaram que o juiz de fora da Bahia deveria exercer o cargo de juiz dos órfãos ${ }^{33}$, contudo informaram que naquele momento isso não se podia praticar pois o ofício havia sido concedido em mercê e se encontrava a muitos anos em poder do beneficiário. No que tocava a formar uma companhia para assistir ao ouvidor de Sergipe, o Conselho considera a medida necessária “[...] porem que a fazenda de Vossa Majestade senão acha em estado de se lhe acrescentar mais esta despesa”. Para que o oficial régio não ficasse sem a proteção necessária para a execução da justiça na comarca, deveriam ser mandados 30 soldados “[...] da mesma forma e maneira que aponta a António Luís da Câmara Coutinho, mudando-se estes nas monções todos os anos" ${ }^{34}$.

Findo o período de consultas as determinações começaram a ser colocadas em prática.

\section{As primeiras nomeações de juízes de fora para o Brasil}

Segundo Faria (2014) o cargo de juiz de fora estava presente na estrutura judiciária portuguesa desde o reinado de Dom Afonso $\mathrm{IV}^{35}$. À época da criação desse cargo, e mesmo posteriormente, o conselho ou câmara municipal era a unidade básica da estrutura judicial e administrativa das cidades portuguesas, cada conselho mantinha certo número de funcionários que exerciam as funções administrativas e judiciais necessárias à vida urbana ${ }^{36}$.

Esses órgãos eram formados por no mínimo dois vereadores e um procurador. Em princípio, esses oficiais da câmara não eram remunerados sendo eleitos localmente. Entre os funcionários responsáveis pelas funções judiciais estavam os juízes ordinários, que assim como os demais membros do conselho eram escolhidos entre os moradores da localidade, o que gerava muitos problemas de jurisdição. A presença de juízes na estrutura das câmaras justifica-se pois essas possuíam "[...] jurisdição em primeira instância sobre (quase) todas as matérias", funcionado como verdadeiros tribunais. Eram inclusive presididas pelos juízes ordinários, com exceção das localidades que contavam com juiz de fora, nessas a direção competia ao titular daquele cargo ${ }^{37}$.

Com intuito de remediar os problemas de jurisdição ocasionados pela nomeação de juízes residentes na localidade foi criado, em 1352, o cargo de juiz de fora, que como o próprio nome explicita era destinado a magistrados de fora da comunidade, que não eram eleitos e sim nomeados pela coroa. Havia ainda mais uma importante diferença entre o juiz ordinário e o de fora, enquanto os juízes ordinários não eram treinados nos caminhos da lei, 
todos os postulantes ao cargo de juiz de fora deveriam ser instruídos no direito romano. Segundo Almeida (1870) o juiz ordinário “[...] era um juiz independente da realeza, e a legislação que executava estava fora do alcance do mesmo poder, e só o costume podia alterala". A nomeação de juízes de fora era uma forma de padronizar a justiça em todas as partes do Reino, expandindo assim a área de influência do rei. Mesmo com as subsequentes alterações na legislação portuguesa, a coroa manteve em suas mãos o poder de nomear os juízes de fora. Consta no Título LXV do Livro I das Ordenações Filipinas “[...] os Juízes ordinários e outros, que Nós de fora mandarmos, devem trabalhar, que nos lugares e seus termos, onde forem Juízes, se não façam malefícios, nem malfeitorias. E fazendo-se, provejam nisso, e procedam contra os culpados com diligência" ${ }^{38}$.

Em seu parecer, Cristóvão de Burgos aponta a incapacidade dos juízes ordinários administrarem corretamente a justiça. Essa seria uma das principais razões para criação do cargo de juízes de fora:

[...] a $1^{\mathrm{a}}$ porque os juízes ordinários como não são letrados e não fazem coisa alguma nem o sabem fazer dão os feitos cíveis a sentenciar aos advogados, e aos mesmos alguma devassa ou querela, quando sucede tira-la para a anunciar, de que se segue maior inconveniente porque se manifesta ao advogado e descobre o segredo da justiça não só daquela que tomou e recebeu o juiz ordinário, mas de todas as mais que se deram perante o ouvidor geral do crime que estão escritas no mesmo livro dos tabeliães. A $2^{\mathrm{a}}$ porque se escusarão as inquietações das parcialidades dos que pretende servir de juízes na câmara, além de que não se pode duvidar que será a câmara mais bem regida e governada assim na despesa como no mais havendo juiz de fora letrado que lhe assista e a vista de uma Relação do que o é por aqueles ${ }^{39}$.

A presença de magistrados letrados nas povoações não era almejada apenas pelos oficiais régios, mas pela população, que constantemente enviava queixas à Relação sobre a atuação dos juízes ordinários. Em junho de 1700, D. João de Lencastre encaminhou correspondência ao Reino, solicitando que fosse criado o cargo de juiz de fora para as novas vilas que haviam sido erigidas no sertão: São Francisco, Cachoeira e Jaguaripe. A ação seria necessária para evitar que queixas dos moradores dessas localidades, sobre a aplicação da justiça pelos juízes ordinários, se amontoassem na Relação, a exemplo do que acontecida nas vilas mais antigas, que contavam apenas com juízes da terra:

Sendo o maior motivo que moveu Vossa Majestade para a ereção das vilas no Recôncavo e sertão desta capitania o poder-se mui prontamente administrar justiça aqueles moradores e castigarem-se com mais facilidade os delitos, tem mostrado a experiência que os juízes ordinários que nelas servem obram tanto pelo contrário que são continuas as queixas nesta Relação das partes que aqueles juízes vão litigar, das injustiças e sem razões que se lhe fazem, umas pelas ignorâncias dos juízes, outras que são as mais, pelos particulares respeitos de seus amigos e parentes, de 
sorte, que nem podem cobrar as dívidas que se lhes devem nem os delinquentes se castigam, obrando mais nestes juízes a sua afeição ou o ódio do que a razão ou justiça $^{40}$.

Parece-nos que, de fato, a presença do juiz de fora trazia benefícios para os moradores das localidades onde esses atuassem. As povoações passavam a contar com um magistrado letrado, conhecedor das leis do Reino e, ao menos teoricamente, imparcial para julgar suas causas.

Em 07 de fevereiro de 1696, foi criado o ofício de juiz de fora para a cidade de Salvador $^{41}$. Foi designado para o cargo José da Costa Correia, que assumiria o posto em 07 de junho de 1696, data em que apresentou sua nomeação aos camaristas que serviam naquele ano $^{42}$.

Antes mesmo de embarcar para o Brasil, em março de 1696, o bacharel solicitou fosse lhe passada a mercê de receber anualmente 80 mil réis de vencimentos pagos pela câmara, no que foi atendido ${ }^{43}$. Além desses vencimentos o titular do cargo fazia jus a algumas pequenas taxas, conhecidas como propinas, “[...] por participação em atos públicos; por julgamento de coimas na Câmara; por vistorias e arrecadações; por assinatura de licenças para os oficiais mecânicos e juramentos dos capitães e oficiais de milícia de ordenança"44.

Contudo os rendimentos dos juízes de fora não se esgotavam nas rendas decorrentes das atividades inerentes a esse oficio. O titular do cargo na Bahia exercia também outras funções na governança da colônia. Devido à falta de oficiais letrados no Brasil e, por vezes, dado a demora da coroa no envio de magistrados para assumir os postos vagos, o acúmulo de funções era frequente, o que aumentava a esfera de atuação desses e sua influência sobre a população local ${ }^{45}$.

Por imposição do decreto que criou o cargo, o juiz de fora da Bahia tinha o ofício de provedor dos defuntos e ausentes ${ }^{46}$, além de exercer a função de provedor dos resíduos e capelas. Como vimos anteriormente, deveria ainda acumular o posto de juiz dos órfãos, ocupação que não pode exercer pois o cargo estava dado em mercê a um morador da capitania. Segundo Mello (2014) as funções que os titulares do cargo de juiz de fora acumulavam na administração da colônia, lhes geravam muitos ganhos, além de uma significativa influência nas transações econômicas da comarca ${ }^{47}$.

Os rendimentos recebidos por José da Costa Correia pelo desempenho de todos seus cargos somavam uma significativa quantia. Segundo informação do chanceler da Relação João da Rocha Pita encaminhada ao Reino em 26 de junho de 1699, por ocasião da residência 
feita no fim do mandato do magistrado, do posto de juiz de fora os vencimentos totais eram de 280 mil réis anuais. Desses, 150 eram pagos pela coroa, 80 pela Câmara e os 50 restantes viriam das propinas. Os ganhos como provedor dos defuntos e ausentes foram avaliados em “[...] cento e dez mil réis de rendimento em cada um ano, havendo respeito a estar este oficio dividido entre o ouvidor da comarca e juiz de fora". Os emolumentos do oficio de provedor dos resíduos e capelas eram estimados em cinquenta mil réis anuais ${ }^{48}$. Somados os vencimentos o ocupante do cargo de juiz de fora da Bahia tinha, nos últimos anos do século XVII, um ordenado anual de 440 mil réis ${ }^{49}$.

Em 28 de janeiro de 1700, André Leitão de Melo foi designado para ocupar o cargo de juiz de fora da Bahia. Antes dessa nomeação fora juiz de fora de Santiago de $\mathrm{Cacem}^{50}$. Eleito para exercer a função por três anos, assumiu o cargo em maio de 1700, ficando no oficio até 1705, sendo substituído por Fernando Pereira de Vasconcelos ${ }^{51}$.

O oficio de juiz de fora da capitania de Pernambuco foi criado em 1700. Porém, o cargo só foi ocupado em 1702, quando foi nomeado como primeiro juiz de fora de Olinda, o doutor Manoel Tavares Pinheiro que tomou posse em 20 de março daquele ano ${ }^{52}$.

Na capitania do Rio de Janeiro, a criação do cargo data de 1701. Contudo, esse só foi ocupado em 1703, quando assumiu o ofício o bacharel Francisco Leitão de Carvalho ${ }^{53}$.

O fato dos ofícios terem sido criados nas cidades sugeridas por Cristóvão de Burgos é uma demonstração de que as informações contidas no seu parecer, juntamente com as apresentadas por Sebastião Cardoso, foram empregadas pela coroa para reorganizar parte do judiciário do Brasil. E não apenas a sugestão de criar os cargos de juiz de fora foi colocada em pratica, outras mudanças que haviam sido sugeridas pelos magistrados em 1681 também foram implementadas.

\section{Novas comarcas e ouvidores}

A hipótese de que os pareceres foram a base de diversas mudanças, em parte da estrutura do judiciário da colônia, parece ficar mais solida quando analisamos a criação de novos cargos de ouvidores para as capitanias.

Enquanto a jurisdição do titular do cargo de juiz de fora limitava-se à câmara que esse dirigia, os ouvidores-gerais tinham alçada sobre toda a extensão das comarcas. Ocupavam, portanto, uma posição hierárquica superior. As atribuições dos ouvidores eram muitas: recebiam novas ações e analisavam recursos de decisões dos juízes que estavam sob sua alçada; supervisionavam a aplicação da justiça na comarca, executando correições periódicas; 
propunham a nomeação de novos tabeliães e eram responsáveis pela promoção das eleições para as câmaras, tinham ainda a incumbência de verificar as rendas e a gestão realizada pelos vereadores; mandar prender os que deviam por suas culpas; além de outras responsabilidades ${ }^{54}$.

Em fevereiro de 1696, na mesma carta régia que criou o oficio de juiz de fora da Bahia, foram instituídos dois cargos de ouvidor. Um deles assumiria o posto de ouvidor do crime em Salvador $^{55}$, enquanto o outro seria ouvidor-geral da nova comarca de Sergipe ${ }^{56}$.

Diogo Pacheco de Carvalho assumiu, em junho de 1696, o cargo de ouvidor de Sergipe. Um ano após tomar posse, em carta datada de 14 de junho de 1697, Diogo relata as autoridades do Reino a situação que encontrou a justiça na capitania. Ao realizar sua primeira correição, 16 anos depois que a última havia sido feita, encontrou 160 casos de mortes violentas sem julgamento, muitas dessas praticadas por poderosos, “[...] muitos dos poderosos faziam e mandavam fazer homicídios e com fabricas e respeitos compravam as justiças" que era responsabilidade dos juízes ordinários. Pela forma que esses administravam a justiça, deixando muitos criminosos impunes, o ouvidor pedia que fossem proibidos de iniciarem novas ações. Segundo o magistrado a impunidade era muito grande. Os que tinham dividas, ainda que já houvesse sentença contra eles, não eram executados por não haver oficiais que realizassem as diligências. Mesmo quando os delinquentes eram capturados, a cadeia da cidade de São Cristóvão, por estar em péssimas condições, não era suficiente para os manter presos: “[...] a cadeia que havia nesta cidade não tinha mais do que o nome de prisão porque todos os anos se rompia muitas vezes pelos mesmos presos". Relatava ainda que pelo aumento da capitania seria necessário criar mais um cargo de escrivão ${ }^{57}$.

A carta do Diogo Pacheco foi vista no Conselho Ultramarino em novembro de 1697. Os conselheiros sugeriram que o rei aumentasse a jurisdição do ouvidor para que ele pudesse agir contra as pessoas poderosas. Informaram não ser possível proibir os juízes ordinários de exercerem suas funções, mas que caso essas não fossem executadas a contento, o ouvidor poderia usar a prerrogativa de iniciar nova ação sobre o mesmo caso. Por fim, defenderam a criação de mais um cargo de escrivão, que deveria ser denominado escrivão da correição ${ }^{58}$. Do relato do ouvidor de Sergipe, depreende-se que a presença de magistrado letrado era de fato necessária para uma melhor aplicação da justiça.

A ouvidoria de Sergipe, criada em 1696, foi fruto de uma ação planejada pela coroa, num esforço para aprimorar os mecanismos de aplicação da justiça, pautado em debates feitos no âmbito do Conselho Ultramarino. Inclui-se nesse contexto a nomeação de juízes de fora 
para Rio de Janeiro, Pernambuco e Bahia, bem como a criação do cargo de juiz de vintena e a fundação de novas vilas no Recôncavo, que trataremos a seguir. Todas essas iniciativas, colocadas em prática na última década do século XVII, apresentam uma intencionalidade que procuramos demonstrar ao longo desse artigo. Não advogamos que as outras duas ouvidorias criadas no final do século XVII; a saber: Paraíba (1688) e São Paulo (1700) ${ }^{59}$; sejam frutos dessa mesma dinâmica.

Apesar do parecer de Cristóvão de Burgos sugerir que fosse indicado ouvidor letrado para a capitania da Paraíba, o que ocorreu em 25 de janeiro de $1688^{60}$, acreditamos que o processo de criação desse cargo, não se enquadra no mesmo planejamento régio que culminou com a instituição da comarca de Sergipe, pelos seguintes motivos: a) documentos comprovam que houve constantes solicitações por parte dos oficiais da Câmara e do capitão-mor da Paraíba para que fosse indicado ouvidor letrado para a capitania ${ }^{61}$; b) um único despacho régio cria tanto o cargo de juiz de fora para Salvador, como os dois ofícios de ouvidor, o que demonstra que esses postos surgiram de um mesmo debate.

Quanto a comarca de São Paulo, sua criação teria sido reflexo da nova dinâmica gerada pela descoberta de ouro no interior da colônia. Segundo Cunha, Nunes (2016), a nova jurisdição "[...] era de fronteira totalmente aberta, foi aquela a partir da qual se desagregaram as novas comarcas e também as novas capitanias"

Como afirmam Cunha, Nunes (2016) o processo de criação de comarcas se deu através de dinâmicas muito variadas "[...] em alguns casos tem raiz em Lisboa, enquanto em outros, mais frequentemente, nos agentes da coroa no território, sobretudo nos governadores e nos ouvidores-gerais $^{63}$. Não podemos, portanto, creditar a criação de todas as comarcas, de finais o século XVII, ao intento régio, contudo acreditamos que ao menos a de Sergipe teria sido fruto dos debates sobre a matéria que ocorreram no Conselho Ultramarino. Demonstrando assim, a intencionalidade régia de baseado nos pareceres dos magistrados, reorganizar parte do judiciário da colônia. Intento que também se manifestou em outras mudanças implementadas na justiça no período.

\section{Postos auxiliares da justiça e outras mudanças na governação da terra}

Criados os cargos de juiz de fora e a nova comarca, faltava ainda conceder justiça aos moradores das regiões mais distantes do sertão que, segundo os pareceres de Sebastião Cardoso e Cristóvão de Burgos, sofriam com a falta de oficiais régios. 
Em janeiro de 1699, o rei ordenou que o governador geral do Brasil criasse nas localidades do sertão um cargo de juiz: "[...] fui servido resolver que em cada freguesia das que tenho mandado formar pelos ditos sertões, haja um juiz a semelhança dos juízes da vintena que há neste Reino, o qual será dos mais poderosos da terra”. Para garantir que esses oficiais pudessem aplicar a lei, deveriam ainda ser instituídos em cada uma das localidades “[...] um capitão mor e mais cabos de milícia, e que nestes postos se nomeiem aquelas pessoas que forem mais poderosas, os quais serão obrigados a socorrer, e a ajudar os juízes dando lhe toda ajuda e favor para as diligências da justiça" ${ }^{\circ 4}$.

$\mathrm{Na}$ estrutura judiciária portuguesa, o juiz de vintena era nomeado pelas autoridades régias para as localidades mais afastadas, com população entre 20 e 50 habitantes, e que não constituíam um conselho, o titular do cargo era escolhido entre os moradores do lugar ${ }^{65}$.

Com intuito de garantir que esses oficiais tivessem condições de aplicar a lei, a coroa determinou a criação dos postos de capitão-mor e cabos de milícia. Ainda com esse intuito o rei determinou que os indivíduos que resistissem a autoridade desses novos juízes, deveriam ser "[...] castigados como se o fizeram aos juízes de fora, e se lhes sequestrem seus bens até sentença final, e que se faça execução por eles no que tocar, as penas pecuniárias que serão maiores por senão poderem executar as corporais"66.

Em junho de 1700, o governador geral do Brasil, D. João de Lencastre, escreveu ao rei informando que tinha já nomeado no sertão alguns capitães e cabos, como lhe havia sido ordenado. Contudo, ressaltava que a presença dessas tropas não seria suficiente para garantir uma boa aplicação da justiça nas povoações do rio São Francisco. Para essas localidades seria necessário criar novos capitães “[...] cada um com 20, ou 25 soldados de cavalo assim da parte desta capitania, como da de Pernambuco, para que estes corram aquele distrito e prendam os delinquentes, que para aqueles sítios costumam ir homiziar-se, por neles terem o melhor seguro, o que não será havendo estes capitães". O governador defende que a presença dessas tropas daria mais eficiência a execução das ordens dos oficiais régios, diminuindo a impunidade. Essas companhias criadas na Bahia e em Pernambuco deveriam trabalhar juntas na captura dos foragidos, tornando assim " $[$...] muito dificultoso o escaparem de ser presos os delinquentes”. Apesar de ter nomeado alguns capitães a ordem de designar os juízes de vintena não estava sendo fácil de ser cumprida. Na correspondência, o governador geral informa ao rei sobre a dificuldade que vinha encontrando para nomear pessoas para esse oficio: “[...] quanto aos juízes da vintena até o presente não acho pessoas capazes e de confiança, porque regularmente os que habitam os sertões são vaqueiros e os que podem ir 
servir desta cidade, e das suas vilas o não querem fazer, por não serem conveniência, nem de que lá o sustentem"

Não encontramos, nos fundos pesquisados, mais documentos que tratassem sobre a criação dos cargos de juízes de vintena durante o período estudado. Isso nos leva a crer que a iniciativa tenha sido abandonada, dada a dificuldade de encontrar pessoas capazes de assumir o cargo, como relatado pelo governador geral. Em muitas situações, não era possível colocar em prática o que havia sido planejado pela coroa, o que não suprime a intencionalidade dessas ações régias.

Sebastião Cardoso e Cristóvão de Burgos afirmavam em seus pareceres que, para uma melhor aplicação da justiça, seria necessário aumentar o número de vilas e cidades tanto no Recôncavo como no sertão. Medida também colocada em prática no final do século XVII.

Analisando o processo de criação de vilas no Brasil colonial, Rhoden (1999) nos apresenta os seguintes números para o período entre 1640 e 1700. Na década de 1640, foram criadas 2 vilas no Brasil. Nos dez anos seguintes, houve um pequeno aumento tendo sido erigidas 6 novas vilas. Entre as décadas de 1660 e 1680, teriam sido criadas apenas 2 vilas em cada decênio. Na última década do período, houve um significativo aumento na criação de vilas, sendo 9 povoações elevadas a essa categoria ${ }^{68}$.

As novas vilas criadas entre 1690 e 1700 foram: Nossa Senhora do Rosário da Cachoeira, Nossa Senhora da Ajuda de Jaguaripe, Camamu, São Francisco da Barra do Sergipe do Conde, Nossa Senhora da Luz dos Pinhais de Curitiba, todas em 1693; Santo Antônio de Sá de Macacú e Santo Amaro das Brotas em 1697; em 1699 Iguaçu e São José de Aquirás em $1700^{69}$. Quatro dessas estavam localizadas na Bahia: Cachoeira, Jaguaripe, Sergipe do Conde e Camamu. Sendo que as 3 primeiras se localizavam na região do Recôncavo e duas delas são nominalmente citadas no parecer de Cristóvão de Burgos, a saber: Jaguaripe ${ }^{70}$ e Cachoeira ${ }^{71}$.

Quando elevadas à categoria de vila, as povoações passavam a contar com uma câmara, o que permitia que os moradores tivessem mais acesso à justiça, já que, esse órgão funcionava como um tribunal de primeira instância. Apesar de não podermos vincular a criação de todas as vilas da década de 1690 ao plano de expandir a justiça no Brasil, acreditamos que, ao menos, as novas vilas do Recôncavo inserem-se no processo de alterações implementadas na justiça da colônia que decorreram dos debates dos pareceres de 1681. 


\section{Conclusão}

As atribuições das câmaras eram muitas, seus oficiais eram responsáveis pela provisão de gêneros alimentícios, limpeza da cidade, segurança pública e justiça de primeira instância. A elas competia ainda a arrecadação dos impostos municipais e alguns tributos régios.

Com tantas atribuições, controlar a câmara significava exercer um significativo controle sobre a localidade. E era em parte isso o que almejava a coroa com a criação dos novos cargos de juiz de fora. Importante salientar que esses postos foram criados nas cidades economicamente mais atrativas da colônia: Salvador que apesar da crise da indústria açucareira ainda era a mais importante fonte de recursos para os cofres régios; Olinda, que formava com Recife um importante núcleo urbano com economia ainda predominantemente canavieira, mas que vinha passando por uma reestruturação econômica e política que se estendia desde a expulsão dos holandeses em 1654; e Rio de Janeiro que já na iminência da descoberta do ouro via sua importância crescer.

Não podemos nos esquecer que o período era de escassez de recursos e aumentar o controle sobre a arrecadação era sem dúvida um expediente importante para diminuir os descaminhos das receitas régias. No momento em que foram criados os cargos a conjuntura econômica era diferente daquela encontrada quando os pareceres foram escritos, mas essas cidades já formavam os principais núcleos urbanos do Brasil e, a darmos crédito aos relatos de Sebastião Cardoso e Cristóvão de Burgos, a aplicação da justiça nessas localidades encontrava muitos problemas devido à falta de oficiais régios. Portanto acreditamos que para além dos motivos econômicos os de ordem política; a saber: promoção de uma melhora na aplicação da justiça nas possessões; suscitaram a criação desses novos postos bem como as demais mudanças promovidas na estrutura judiciária da colônia. As necessidades dos súditos foram consideradas no momento de colocar em prática essas mudanças, como não poderia deixar de ser, já que, no âmbito do Antigo Regime prover a justiça era uma prerrogativa régia. Há também que se destacar que nem sempre o planejado foi passível de execução, como pudemos ver no caso da nomeação dos juízes de vintena. Contudo mesmo o insucesso da empreitada não suprime a intencionalidade das ações régias que, em seu conjunto, visavam aprimorar a justiça que era concedida aos moradores do Brasil. 


\section{Notas}

${ }^{1}$ Dentro da teoria corporativa da sociedade e do poder, a promoção da justiça era a primeira atribuição régia, secundariamente cabia ao monarca a garantia da paz. Ao rei pertencia a justiça suprema "[...] concretizada no conhecimento das causas em última instância, quer por via ordinária (caso das apelações e agravos), quer por via extraordinária (caso das revisões de sentenças)". A suprema jurisdição (suprema iurisdictio) garantia ainda “[...] o exclusivo real de estabelecer lei geral para todo o reino, indelegável, bem como a prerrogativa de criar magistrados (i.é, oficiais dotados de jurisdição) e de vigiar o cumprimento das suas atribuições (sindicância, correição), esta delegável e, efetivamente, delegada.” Esses poderes apresentavam uma ideia de limitação, sendo por um lado considerados poderes deveres, vinculados a certas finalidades e não podendo ser usados arbitrariamente. Por outro lado, o rei era apenas o garantidor dos direitos estabelecidos, seu papel não era de reorganizar a sociedade, mas mantê-la dentro dos parâmetros preestabelecidos, HESPANHA. António Manuel. As vésperas do Leviathan: Instituições e poder político Portugal - séc. XVII. Coimbra: Livraria Almedina, 1994, pp. 487-489. O rei representava a cabeça do corpo social, sendo o poder dividido entres os vários membros desse corpo, "[...] a função da cabeça não é pois a de destruir a autonomia do corpo social, mas a de, por um lado representar externamente a unidade do corpo e, por outro, manter a harmonia entre todos os seus membros, atribuindo a cada um aquilo que lhe é próprio, garantindo a cada qual o seu estatuto (foro, privilégio, direito); numa palavra realizando a justiça”, XAVIER, Ângela Barreto e HESPANHA, António Manuel. A concepção corporativa da sociedade. In: MATTOSO, José (dir.). História de Portugal. vol. IV: O Antigo Regime (16201807). Lisboa: Editorial Estampa, 1998, pp. 114-115. Esses princípios se difundiram em Portugal, durante a época moderna, graças a influência da filosofia jesuítica da Nova Escolástica. Os teóricos neotomistas, inspirados pelo pensamento medieval de indispensabilidade de todos os ramos da sociedade para concepção da ordem política, defendiam "[...] uma ordem estatal que deveria tangenciar a autonomia político-jurídica dos corpos sociais, sendo a justiça o fim lógico do poder político. Essas ideias iriam encontrar fundamento a partir de uma reinterpretação do pensamento escolástico, que defendia a existência de uma ordem natural das coisas, harmonizando-se em função do Bem Supremo e sujeita a uma regulação cósmica", ATALLAH, Claudia Cristina Azeredo. Da justiça em nome d'El Rey: ouvidores e inconfidência na capitania de Minas Gerais (Sabará, 1720 - 1777). Tese (Doutorado em História) - Instituto de Ciências Humanas e Filosofia, Universidade Federal Fluminense, 2010 pp. 32-33.

${ }^{2}$ SALGADO, Graça. Fiscais e meirinhos: a administração no Brasil colonial. Rio de Janeiro: Nova Fronteira, 1985 p. 73.

${ }^{3}$ D. Pedro assumira o trono português inicialmente como regente no lugar de D. Afonso VI, seu irmão, que fora afastado por sua suposta incapacidade de consumar o casamento e gerar herdeiros para perpetuação da dinastia de Bragança. D. Afonso também era acusado de permitir que o conde de Castelo Melhor, titular do cargo de escrivão da puridade, governasse em seu lugar. D. Pedro II seria coroado rei apenas após a morte de seu irmão em 1683, foi cognominado "o Pacifico" pois durante seu reinado foram firmados tratados de paz com holandeses (1661) e espanhóis (1668) o que deu início a um ciclo de relativa calmaria nas relações portuguesas com as demais potências europeias. Uma importante contribuição ao estudo da biografia de D. Pedro foi dada pela obra: LOURENÇO, Maria Paulo Marçal. Dom Pedro II, o pacífico (1648-1706). Lisboa: Temas \& Debates, 2010 passim.

${ }^{4}$ Arquivo Histórico Ultramarino (AHU), Carta do procurador da Fazenda do Brasil, Sebastião Cardoso de Sampaio, ao príncipe regente [D.Pedro], relatando o estado das coisas da fazenda, justiça e demais governo do Brasil, Bahia, série Luísa da Fonseca, cx. 24, doc. 2972 e AHU, Carta do desembargador Cristóvão de Burgos ao príncipe regente [D. Pedro], sobre os remédios a aplicar ao estado do Brasil, Bahia, série Luísa da Fonseca, cx. 25 , docs. 3018 a 3020

${ }^{5}$ O Tribunal da Relação era a instância máxima da justiça em terras brasileiras. Criado inicialmente em 1609 foi extinto em 1625 devido a guerra com os holandeses, retomando atividades em 1652. O tribunal era responsável por acolher os recursos de ações já julgadas por oficiais de instâncias inferiores, como os ouvidores das capitanias e do ouvidor geral. O órgão era presidido por um chanceler, segundo cargo mais importante na governação da terra, estando abaixo apenas do governador-geral, SCHWARTZ, Stuart B. Burocracia e Sociedade no Brasil Colonial: A suprema corte da Bahia e seus juízes 1609 - 1751. São Paulo, Editora Perspectiva, 1979 pp. $50-54$.

${ }^{6}$ BIBLIOTECA NACIONAL. Documentos Históricos - Consultas do Conselho Ultramarino Bahia 1673-1683, vol. 88. Rio de Janeiro: Biblioteca Nacional, 1950 pp. 138-139. A carta dos desembargadores data de 22/08/1677, tendo sido vista no Conselho Ultramarino em 18 de julho do ano seguinte. Ao analisar a matéria tanto o procurador da fazenda como os conselheiros do Ultramarino concordaram com os argumentos apresentados pelos desembargadores, deixando nas mãos de D. Pedro a decisão de instituir ou não o cargo naquele momento.

${ }^{7}$ SCHWARTZ, Op. cit., 1979 p. 214. 
${ }^{8}$ SALGADO, Op. cit., 1985 p. 80.

${ }^{9}$ MELLO, Isabele de Matos Pereira de. Os ministros da justiça na América portuguesa: ouvidores-gerais e juízes de fora na administração colonial (séc. XVIII). Revista de História, São Paulo, n. 171, 2014 p. 358.

${ }^{10}$ Dada todas as atribuições das câmaras, os motivos econômicos foram sem dúvida muito considerados no momento de se decidir pela criação dos cargos de juiz de fora " [...] no caso especifico das cidades marítimas mais importantes da América portuguesa, uma das principais razões para a criação do cargo de juiz de fora foi sem dúvida a necessidade sentida pela Coroa de intervir nas funções administrativas e financeiras especificamente tributarias - das câmaras coloniais, para controlar os descaminhos e os possíveis prejuízos da Real Fazenda", BICALHO, Maria Fernanda. A cidade e o império: o Rio de Janeiro no século XVIII. Rio de Janeiro: Civilização Brasileira, 2003 p. 349.

${ }^{11}$ CAMARINHAS, Nuno. O aparelho judicial ultramarino português. O caso do Brasil (1620-1800). Almanack braziliense, São Paulo, n. 9, 2009 p. 85.

${ }^{12} \mathrm{O}$ autor usa seis tópicos para explicar a situação da justiça e o mesmo número para a fazenda. $\mathrm{O} 13^{\circ}$ tópico é empregado para tratar da guerra, já que o governo do Brasil " [...] como o de todos os reinos e republicas consiste, e se divide em três pontos, justiça, fazenda e guerra". AHU-BA, série Luísa da Fonseca, cx. 24, doc. 2972.

${ }^{13}$ MELLO, Marcia Eliane Alves de Souza e. O regimento das missões: poder e negociação na Amazônia portuguesa. CLIO - Revista de Pesquisa Histórica. Recife, n. 27, v. 1, pp. 46-75, 2009 pp. 53 e 72.

${ }^{14}$ Os juízes ordinários eram escolhidos entre os moradores das localidades, por essa razão eram conhecidos também como juízes da terra. Cada conselho contava normalmente com dois desses juízes, os titulares desse cargo geralmente eram cidadãos comuns que exerciam a função pelo período de um ano, não sendo treinados nos caminhos da lei. Como eram eleitos dentre os moradores da localidade, os juízes ordinários estavam sujeitos as pressões que eventualmente poderiam ser exercidas pelos seus pares, o que dificultava a aplicação imparcial das leis do Reino. Havia também o risco do titular do cargo, mesmo sem pressões externas, tomar decisões que beneficiassem seus familiares ou amigos, SCHWARTZ, Op. cit., 1979 p. 5.

${ }^{15}$ AHU-BA, série Luísa da Fonseca, cx. 24, doc. 2972.

${ }^{16}$ Idem. Em outro documento confeccionado por Cardoso, em 1675 quando ainda ocupava o cargo de chanceler da Relação, é explicado como se dava a diferenciação entre as terras do Recôncavo e as do sertão na Bahia: "A terras do distrito desta capitania da Bahia de todos os Santos distinguiram e divisaram os moradores dela em duas partes, segundo a diversa cultura, que lhe aplicavam e diversos nomes que lhe puseram. A primeira parte que começa imediatamente a cidade e se estende em área junto ao mar desta Bahia por espaço de trinta léguas em circuito dela, com largura de dez ou doze foi imposto o nome de Recôncavo, e nela estão fabricados cento e trinta engenhos de açúcar, muitos canaviais, algumas roças de farinhas e o restante do tal Recôncavo se conserva ainda em matos de que se tiram lenhas e madeiras para as fabricas dos engenhos, e benefício do açúcar. A segunda parte chamam comumente de sertão que contem em si a terra que corre para o ocidente, e interior deste Estado, desde o sobredito Recôncavo até confinar com a demarcação do Peru, e Nova Espanha. Nesta segunda parte tem descoberto e penetrado alguns moradores a distância proporcionada a possibilidade de seu cabedal e indústria, na qual ocuparam com gados aquela terra, que nela se acha com comodidade de pastos e aguas para procriação dos ditos gados". AHU, Consulta do Conselho Ultramarino ao príncipe regente [D. Pedro], sobre carta do desembargador sindicante Sebastião Cardoso de Sampaio, que estava na Bahia, informando do número de pessoas com terras de sesmarias e do excesso com que se tem dado terras de sesmaria a várias pessoas, Bahia, série Luísa da Fonseca, cx. 23, docs. 2737-2738.

${ }^{17}$ AHU-BA, série Luísa da Fonseca, cx. 24, doc. 2972.

${ }^{18}$ Idem.

${ }^{19}$ Idem.

${ }^{20}$ Idem.

${ }^{21}$ AHU, Consulta do Conselho Ultramarino sobre as diligências que se encarregaram a Sebastião Cardoso de Sampaio, no Brasil, e licença que pede para voltar ao Reino, Bahia, série Luísa da Fonseca, cx. 23, docs. 27392741.

${ }^{22}$ AHU-BA, série Luísa da Fonseca, cx. 23, docs. 2737-2738.

${ }^{23}$ Os dados sobre a trajetória de Cristóvão de Burgos foram compilados das seguintes fontes: AHU, Consulta do Conselho Ultramarino ao rei [D. João IV], sobre a nomeação de Cristóvão de Burgos para o lugar de desembargador dos agravos da nova Relação da Bahia, em que foi provido o licenciado Simão Álvares de La Penha que preferiu o lugar de provedor da fazenda que estava exercitando, Bahia, série Luísa da Fonseca, cx. 12, doc. 1473; AHU-BA, série Luísa da Fonseca, cx. 25, docs. 3018 a 3020 e SCHWARTZ, Op. cit., 1979 pp. 303-304 e 312.

${ }^{24}$ AHU-BA, série Luísa da Fonseca, cx. 25, docs. 3018 a 3020.

${ }^{25}$ Idem. 
${ }^{26}$ Idem.

${ }^{27}$ Idem

${ }^{28}$ Idem

${ }^{29}$ Idem.

30 A carta de Câmara Coutinho datada de 12/10/1695 inicia-se com o seguinte trecho "É Vossa Majestade servido que vendo eu os dois papeis que fizeram um o desembargador Cristóvão de Burgos e outro o desembargador Sebastião Cardoso, e juntamente as três consultas que o Conselho Ultramarino fez principalmente a de 19 de agosto de 1695 e a consulta do Desembargo do Paço de 22 de julho deste mesmo ano". A partir dessa afirmação sabemos que antes do parecer de 19/08/1695 o Conselho havia feito mais 2 consultas sobre o caso, as quais não tivemos acesso. Como o assunto tratava da administração da justiça houve ainda uma consulta ao Desembargo do Paço, instância mais elevada do judiciário português. AHU, Consulta do Conselho Ultramarino ao rei [D. Pedro II], interpondo parecer sobre informações dos desembargadores Cristóvão de Burgos e Sebastião Cardoso de Sampaio, relativas à falta de juízes de fora e ouvidores de comarcas, em Sergipe, Rio de Janeiro, Bahia e Pernambuco, Bahia, série Luísa da Fonseca, cx. 31, doc. 3921.

${ }^{31}$ Idem

${ }^{32}$ Idem.

${ }^{33}$ Enquanto o juiz de fora era uma judicatura reinol, o juiz dos órfãos era um cargo exercido a nível concelhio. Dentre as funções que o titular desse cargo exercia estavam: “[...] cuidar dos órfãos, de seus bens e rendas, fazer um levantamento do número de órfãos do lugar [...] fazer a partilha dos bens dos órfãos" SALGADO, Op. cit., 1985 pp. 262-263.

${ }^{34}$ AHU, Consulta do Conselho Ultramarino ao rei [D. Pedro II], sobre a criação de ouvidores para a cidade da Bahia e Sergipe, das atribuições do juiz de fora e almotacé-mor e outras alterações no âmbito militar, judicial e administrativo, Bahia, série Luísa da Fonseca, cx. 31, doc. 3954.

35 FARIA, Diogo Nuno Machado Pinto. Juízes indesejados? A contestação aos juízes de fora no Portugal medieval (1352-1521). Cadernos do Arquivo Municipal, Lisboa, n. 2, s. 2, jul./jun. 2014 p. 20.

${ }^{36}$ SCHWARTZ, Op. cit., 1979 p. 4.

${ }^{37}$ MONTEIRO, Nuno Gonçalo Freitas. Os concelhos e as comunidades. In: MATTOSO, José (dir.). História de Portugal. vol. IV: O Antigo Regime (1620-1807). Lisboa: Editorial Estampa, 1998 p. 270.

${ }^{38}$ ALMEIDA, Cândido Mendes de. Codigo Philippino ou Ordenações e Leis do Reino de Portugal recopiladas por mandado D'El-Rey D. Philippe I. Rio de Janeiro: Typographia do Instituto Philomathico, Livro I, 1870 p. 134.

${ }^{39}$ AHU-BA, série Luísa da Fonseca, cx. 25, docs. 3018 a 3020.

${ }^{40}$ AHU, Carta do governador-geral do Brasil, D. João de Lencastre ao rei [D. Pedro II], sobre a necessidade de se criarem mais quatro postos juízes de fora, para as vilas de São Francisco, Cachoeira e Jaguaripe. Bahia, série Luísa da Fonseca, cx. 34, doc. 4320

${ }^{41}$ AHU, Decreto do rei D. Pedro II constituindo os cargos de juiz de fora e ouvidores na Bahia, Bahia, avulsos, cx. 3, doc. 253.

${ }^{42}$ SOUSA, Avanete Pereira. Poder local e cotidiano: A Câmara de Salvador no século XVIII. Dissertação (Mestrado em História) - Faculdade de Filosofia e Ciências Humanas, Universidade Federal da Bahia, Salvador, 1996 p. 43.

${ }^{43}$ AHU, Consulta do Conselho Ultramarino ao rei [D. Pedro II], sobre requerimento de José da Costa Correia, nomeado juiz de fora da cidade da Bahia, solicitando se lhe paguem, cada ano, de sua aposentadoria, oitenta mil réis e que os levem em conta os oficiais da Câmara, nas rendas da mesma, Bahia, série Luísa da Fonseca, cx. 31 , doc. 3986.

${ }^{44}$ SOUSA, Op. cit., 1996 p. 45.

${ }^{45}$ MELLO, Op. cit., 2014 p. 372.

${ }^{46}$ AHU-BA, avulsos, cx. 3, doc. 253.

${ }^{47}$ MELLO, Op. cit., 2014 p. 376.

${ }^{48}$ AHU, Carta do chanceler da Bahia, João da Rocha Pita ao rei [D. Pedro II], sobre a avaliação do ofício de juiz de fora da Bahia e mais lugares anexos, Bahia, série Luísa da Fonseca, cx. 33, doc. 4222.

${ }^{49} \mathrm{O}$ valor recebido pelo juiz de fora da Bahia era bastante significativo. Na metade do século XVIII um desembargador da Relação recebia por volta de 1 conto e 200 mil réis de vencimentos, dos quais: 600 mil de ordenado, 270 mil de propinas ordinárias e 330 mil de propinas extras, SCHWARTZ, Op. cit., 1979 p. 217. O desembargador que deveria ter muito mais anos de serviços prestados a coroa recebia aproximadamente 3 vezes o salário do juiz de fora. Dado os significativos rendimentos o oficio de juiz de fora da Bahia provavelmente possuía uma preeminência frente a outras localidades do Reino.

${ }_{50}$ AHU, Carta de mercê do rei [D. Pedro II] do cargo de juiz de fora da Bahia ao bacharel André Leitão de Melo, Bahia, série Luísa da Fonseca, cx. 34, doc. 4275. 
${ }_{52}^{51}$ SOUSA, Op. cit., 1996 pp. 43-44.

${ }^{52}$ ASSIS, Virgínia Maria Almoêdo de. Ofícios do rei: a circulação de homens e idéias na Capitania de Pernambuco. In: XXV Simpósio Nacional de História - História e Ética, Fortaleza: ANPUH, 2009 p. 3.

${ }^{53}$ MELLO, Op. cit., 2014 p. 360.

${ }^{54}$ Idem p. 369.

${ }^{55}$ SCHWARTZ, Op. cit., 1979 p. 205.

${ }^{56}$ CUNHA, Mafalda Soares da e NUNES, António Castro. Territorialização e poder na América portuguesa. A criação de comarcas, séculos XVI-XVIII. Tempo. Niterói (online), v. 22, n. 39, jan./abr. 2016 p. 10.

${ }^{57}$ AHU, Consulta do Conselho Ultramarino ao rei [D. Pedro II], sobre carta do ouvidor-geral de Sergipe, Diogo Pacheco de Carvalho, informando ter tomado posse daquele lugar e mandado construir uma cadeia, devido a saber de número elevado de mortes violentas, Bahia, série Luísa da Fonseca, cx. 32, docs. 4081 e 4082. ${ }^{58}$ Idem.

${ }^{59}$ CUNHA;NUNES, Op. cit., 2016 p. 10.

${ }^{60}$ MENEZES, Mozart Vergetti de. Jurisdição e poder nas capitanias do Norte (1654-1755). Saeculum - Revista de História. João Pessoa, n. 14, jan./jun. 2006 p. 21.

${ }^{61}$ Em 18/01/1675 a Câmara da Paraíba encaminhou correspondência ao Ultramarino tratando sobre o assunto, a mesma foi vista em março daquele ano tendo despacho favorável dos membros do conselho. AHU, Consulta do Conselho Ultramarino, ao príncipe regente D. Pedro, sobre o requerimento dos juizes, vereadores e ministros do Senado da Câmara da cidade de Nossa Senhora das Neves da Paraíba, solicitando ouvidor letrado que administre justiça na capitania, Paraíba, cx. 1, doc. 91. Sobre o assunto ver também: AHU, Consulta do Conselho Ultramarino, ao rei D. Pedro II, sobre a carta do capitão-mor da Paraíba, António da Silva Barbosa, solicitando ouvidor letrado para a capitania ou ir a ela em correição o ouvidor-geral de Pernambuco, Paraíba, cx. 2, doc. 144.

${ }_{62}^{62}$ CUNHA;NUNES, Op. cit., 2016 p. 16.

${ }^{63} \mathrm{Idem}$.

${ }^{64}$ AHU, Carta régia do rei D. Pedro II ao governador-geral do Brasil João de Lencastre mandando criar, em cada freguesia do sertão, capitães-mor e cabos de milícia com obrigação de socorrerem e ajudarem os juízes de vintena nas suas diligências e aplicação de penas, Bahia, avulsos, cx. 3, doc. 277. A exemplo do que aconteceu com outras ordens régias expedidas no período, está foi também discutida no Conselho Ultramarino antes de ser colocada em prática. Em 23/11/1698 os conselheiros emitiram parecer favorável à criação dos novos cargos de cabos de milícias, que ficariam responsáveis por "[...] socorrer e ajudar os juízes, que de cinco em cinco léguas deve haver". Demonstrando que a decisão de criar os postos de juízes partiu da coroa. AHU, Parecer do Conselho Ultramarino sobre a concessão de sesmarias e criação de cabos de milícias, Bahia, avulsos, cx. 3, doc. 274.

${ }^{65}$ SALGADO, Op. cit., 1985 p. 75.

${ }^{66}$ AHU-BA, avulsos, cx. 3, doc. 277.

${ }^{67}$ AHU-BA, série Luísa da Fonseca, cx. 34, doc. 4320.

${ }^{68}$ RHODEN, Luíz Fernando. Urbanismo no Rio Grande do Sul: origens e evolução. Porto Alegre: Editora PUCRS, 1999 p. 75.

${ }^{69}$ AZEVEDO. Aroldo de. Vilas e cidades do Brasil colonial. Terra Livre - AGB. São Paulo, n. 10, jan-jul 1992 pp. 36-37.

70 "No recôncavo da Bahia da barra para dentro onde se navega por mar no rio chamado Jagoaripe coisa de 15 leguas da cidade está a freguesia de Nossa Senhora da Ajuda, na qual por um rol que eu vi das confissões indo ali há coisa de 300 vizinhos seus fregueses que vivem espalhados por diversos rios e estrados que ali faz o mar e desaguam este rio e outros mais, é muito necessário criar-se um conselho com jurisdição pelos muitos delitos que aqui sucedem e dificuldade que há de acudirem lá os juízes da cidade inda quando foram mais diligentes do que são [...]"AHU-BA, série Luísa da Fonseca, cx. 25, docs. 3018 a 3020.

71 "E indo pelo afamado rio Parana-açu coisa de 15 leguas da cidade por mar está o porto chamado de Cachoeira e sitio de Nossa Senhora do Rosário, e dai mais 4 leguas que vem a ser da cidade 18 ou 20 está o lugar da Varge onde me parece que está uma igreja de Santo Antônio porque nunca lá cheguei nem passei da igreja de Nossa Senhora do Rosário aonde eu mandava vir os moradores para as devassas. Neste lugar da Varge se pode principiar uma boa vila porque há muitos anos me disseram que havia coisa de 30 vizinhos juntos e deve hoje haver mais e espelhados é todo o distrito dos Campos da Cachoeira mui povoado de muitas e grossas fazendas das de tabaco e currais de gado". AHU-BA, série Luísa da Fonseca, cx. 25, docs. 3018 a 3020. 


\section{Referências Bibliográficas}

ALMEIDA, Cândido Mendes de. Codigo Philippino ou Ordenações e Leis do Reino de Portugal recopiladas por mandado D'El-Rey D. Philippe I. Rio de Janeiro: Typographia do Instituto Philomathico, Livro I, 1870.

ASSIS, Virgínia Maria Almoêdo de. Ofícios do rei: a circulação de homens e idéias na Capitania de Pernambuco. In: XXV Simpósio Nacional de História - História e Ética, Fortaleza: ANPUH, 2009.

ATALLAH, Claudia Cristina Azeredo. Da justiça em nome d'El Rey: ouvidores e inconfidência na capitania de Minas Gerais (Sabará, 1720 - 1777). 2010. 284 f. Tese (Doutorado em História) - Instituto de Ciências Humanas e Filosofia, Universidade Federal Fluminense, 2010.

AZEVEDO. Aroldo de. Vilas e cidades do Brasil colonial. Terra Livre - AGB. São Paulo, n. 10, pp. 23-78, jan-jul 1992.

BIBLIOTECA NACIONAL. Documentos Históricos - Consultas do Conselho Ultramarino Bahia 1673-1683, vol. 88. Rio de Janeiro: Biblioteca Nacional, 1950.

BICALHO, Maria Fernanda. A cidade e o império: o Rio de Janeiro no século XVIII. Rio de Janeiro: Civilização Brasileira, 2003.

CAMARINHAS, Nuno. O aparelho judicial ultramarino português. O caso do Brasil (16201800). Almanack braziliense, São Paulo, n. 9, pp. 84-102, 2009.

CUNHA, Mafalda Soares da e NUNES, António Castro. Territorialização

e poder na América portuguesa. A criação de comarcas, séculos

XVI-XVIII. Tempo. Niterói (online), v. 22, n. 39, p. 1 - 30, jan./abr. 2016. Disponível em: < http://www.scielo.br/pdf/tem/v22n39/1413-7704-tem-22-39-00001.pdf> Acesso em:

25/11/2017

FARIA, Diogo Nuno Machado Pinto. Juízes indesejados? A contestação aos juízes de fora no Portugal medieval (1352-1521). Cadernos do Arquivo Municipal, Lisboa, n. 2, s. 2, pp. 19-37, jul./jun. 2014.

HESPANHA. António Manuel. As vésperas do Leviathan: Instituições e poder político

Portugal - séc. XVII. Coimbra: Livraria Almedina, 1994.

LOURENÇO, Maria Paulo Marçal. Dom Pedro II, o pacífico (1648-1706). Lisboa: Temas \& Debates, 2010.

MELLO, Isabele de Matos Pereira de. Os ministros da justiça na América portuguesa: ouvidores-gerais e juízes de fora na administração colonial (séc. XVIII). Revista de História, São Paulo, n. 171, pp. 351-381, 2014.

MELLO, Marcia Eliane Alves de Souza e. O regimento das missões: poder e negociação na Amazônia portuguesa. CLIO - Revista de Pesquisa Histórica. Recife, n. 27, v. 1, pp. 46-75, 2009.

MENEZES, Mozart Vergetti de. Jurisdição e poder nas capitanias do Norte (1654-1755).

Saeculum - Revista de História. João Pessoa, n. 14, p. 11 - 25, jan./jun. 2006. Disponível em <http://periodicos.ufpb.br/ojs/index.php/srh/article/viewFile/11339/6453> Acesso em:

25/11/2017

MONTEIRO, Nuno Gonçalo Freitas. Os concelhos e as comunidades. In: MATTOSO, José (dir.). História de Portugal. vol. IV: O Antigo Regime (1620-1807). Lisboa: Editorial Estampa, pp. 269-295, 1998.

RHODEN, Luíz Fernando. Urbanismo no Rio Grande do Sul: origens e evolução. Porto Alegre: Editora PUCRS, 1999 
SALGADO, Graça. Fiscais e meirinhos: a administração no Brasil colonial. Rio de Janeiro: Nova Fronteira, 1985.

SCHWARTZ, Stuart B. Burocracia e Sociedade no Brasil Colonial: A suprema corte da Bahia e seus juízes 1609 - 1751. São Paulo, Editora Perspectiva, 1979

SOUSA, Avanete Pereira. Poder local e cotidiano: A Câmara de Salvador no século XVIII. 1996. 213 f. Dissertação (Mestrado em História) - Faculdade de Filosofia e Ciências Humanas, Universidade Federal da Bahia, Salvador, 1996.

XAVIER, Ângela Barreto e HESPANHA, António Manuel. A concepção corporativa da sociedade. In: MATTOSO, José (dir.). História de Portugal. vol. IV: O Antigo Regime (16201807). Lisboa: Editorial Estampa, pp. 113 - 140, 1998. 